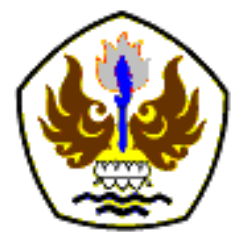

INFOMATEK

Volume 23 Nomor 1 Juni 2021

\title{
TINGKAT PENCEMARAN UDARA CO AKIBAT LALU LINTAS DENGAN MODEL PREDIKSI UDARA SKALA MIKRO DI JALAN SUDIRMAN JAKARTA
}

\author{
Fyra Catleya, Yonik Meilawati Yustiani*, Astri Widiastuti Hasbiah \\ Program Studi Teknik Lingkungan - Fakultas Teknik \\ Universitas Pasundan
}

\begin{abstract}
Abstrak: Lalu lintas kendaraan merupakan salah satu sumber pencemaran udara pada suatu kota. Jakarta sebagai ibukota Indonesia berpotensi memiliki kualitas udara yang buruk akibat kegiatan lalu lintas ini. Karbon monoksida (CO) terbentuk pada pembakaran mesin kendaraan berbahan bakar minyak yang dapat mempengaruhi kesehatan manusia. Jalan Sudirman adalah lokasi di Kota Jakarta dengan tingkat kepadatan lalu lintas yang tinggi. Penelitian ini bertujuan untuk memperoleh tingkat pencemaran udara dengan parameter $\mathrm{CO}$ hasil pemodelan prediksi pada lokasi Jalan Sudirman Jakarta tersebut. Model yang digunakan adalah model prediksi skala mikro. Sampling dilakukan untuk mengukur konsentrasi $\mathrm{CO}$ pada 3 kondisi kepadatan yaitu hari kerja penuh, setengah hari kerja dan hari libur. Tiap hari sampling, pengukuran dilaksanakan 3 kali untuk mewakili kondisi jam puncak di pagi hari, siang dan sore hari. Hasil penelitian dan perhitungan memperlihatkan bahwa prediksi konsentrasi CO yang dihasilkan oleh kendaraan dengan pemodelan berada diantara 5364 ppm hingga 12469 ppm. Konsentrasi CO paling tinggi terprediksi pada hari Senin sore, sedangkan paling rendah terhitung pada hari Sabtu pagi. Secara umum, hasil prediksi menunjukkan bahwa konsentrasi CO di ruas Jalan Sudirman Jakarta masih memenuhi baku mutu.
\end{abstract}

Kata kunci: karbon monoksida, pencemaran udara, pencemar sumber garis

\section{PENDAHULUAN}

Udara merupakan media yang terhubung langsung ke tubuh manusia melalui sistem pernapasan. Udara yang seharusnya masuk ke tubuh manusia dan makhluk hidup lainnya seharusnya dalam keaadan yang baik, yaitu udara yang tidak mengandung polutan (Hasbiah dkk., 2016 [1]). Namun polutan terus

\footnotetext{
*)yonik@unpas.ac.id
}

Pertama diterima: 3 Mei 2021

Direvisi: 19 Mei 2021

Disetujui untuk publikasi: 20 Mei 2021 dihasilkan karena aktivitas alami atau aktivitas manusia.

Sumber-sumber pencemaran udara dapat dibagi dalam dua kelompok besar, sumber alamiah dan akibat perbuatan manusia. Sumber yang diakibatkan dari proses atau kegiatan alam dapat berasal dari kebakaran hutan, kegiatan gunung berapi, dan lain-lain. Sumber pencemaran yang diakibatkan oleh manusia berasal dari sisa pembakaran bahan bakar minyak limbah industri sisa pembakaran dari gas alam, batu bara, dan minyak, dan 
pembakaran sisa pertanian, hutan, dan sampah. Pencemaran udara yang dialami oleh perkotaan mayoritas berasal dari kegiatan manusia karena tingginya mobilitas masyarakat perkotaan.

Mobilitas memiliki arti pergerakan atau perpindahan dari satu tempat ke tempat lain. Dalam implementasinya membutuhkan alat yang dapat mendukung. Bidang yang selalu dikaitkan adalah transportasi. Proses perpindahan memerlukan sarana dan prasarana transportasi, sarana yang dimaksud adalah kendaraan sedangkan prasarana yaitu jalan dan pendukungnya (Fahmi dan Mawardi, W. H., 2007 [2]).

Kota Jakarta yang berperan sebagai Ibu Kota Indonesia memiliki jumlah kendaraan tertinggi di Indonesia. Berdasarkan BPS DKI Jakarta, jumlah kendaraan di DKI Jakarta pada tahun 2019 mencapai 22.858.744 unit atau 14,8\% dari keseluruhan jumlah kendaraan di Indonesia yang berjumlah 154.376 .369 unit (BPS DKI Jakarta, 2019 [3]). Kendaraan bermotor yang terus berkembang secara kuantitas dan kualitas tidak hanya memberikan manfaat, namun juga dampak buruknya yaitu polusi. Berdasarkan berbagai informasi, kendaraan bermotor menghasilkan gas-gas pencemar diantaranya karbon monoksida (CO), nitrogen oksida $\left(\mathrm{NO}_{\mathrm{x}}\right)$, hidrokarbon $(\mathrm{HC})$, Sulfur dioksida $\left(\mathrm{SO}_{2}\right)$, timah hitam $(\mathrm{Pb})$, dan karbon dioksida $\left(\mathrm{CO}_{2}\right)$, dari beberapa jenis gas-gas tersebut, $\mathrm{CO}$ memiliki presentase paling besar, yaitu sebanyak 7080\% (Maryanto, 2009 [4]).

Salah satu langkah penting yang dilakukan dalam proses studi lingkungan adalah melakukan prediksi dampak pada suatu komponen lingkungan, model kualitas udara dipergunakan untuk mengevaluasi dampak dari sumber emisi lalu lintas terhadap kualitas lingkungan. Model menunjukkan bahwa besarnya konsentrasi polutan dipengaruhi oleh banyaknya emisi yang dikeluarkan sumber. Sedangkan pada kasus jalan raya emisi yang dikeluarkan oleh kendaraan bermotor dipengaruhi oleh karakteristik lalu lintas (Hoesodo, 2004 [5]).

Dalam penelitian ini studi lingkungan dilakukan dengan memprediksi konsentrasi CO di udara yang dilepaskan oleh kendaraan dengan pemodelan di Jalan Jendral Sudirman Jakarta Pusat dengan beberapa pertimbangan, yaitu merupakan area perkantoran, terdapat beberapa tempat umum seperti diantaranya pusat perbelanjaan, sekolah, hotel, dan restaura. Pada jalan tersebut memiliki 2 arus berbeda sehingga menjadi akses ke berbagai tujuan yang menjadikan volume kendaraan tinggi. Selain itu pada jalan tersebut jenis kendaraan bervariasi sehingga dapat merepresentasikan jumlah polutan yang dikeluarkan oleh jenis kendaraan yang berbeda-beda. Pada Jalan 
Jendral Sudirman Jakarta belum ada penelitian yang menunjukkan tingkat konsentrasi $\mathrm{CO}$, maka dilakukan penelitian ini.

\section{METODOLOGI}

\subsection{Lokasi}

Lokasi penelitian yaitu di Jalan Sudirman Jakarta Selatan. Penentuan titik pengamatan diawali dengan melihat kondisi lalu lintas melalui situs www.tomtom.com, yaitu laman yang navigasi perjalanan yang juga memperlihatkan kondisi kepadatan lalu lintas. Tahap selanjutnya adalah mendatangi beberapa lokasi yang telah ditentukan dari situs tersebut untuk menganalisis kelebihan dan kekurangan lokasi tersebut apabila dijadikan lokasi penelitian.

Penentuan lebih detil tempat pengamatan dilakukan dengan pertimbangan sebagai berikut:

1. Jalan tersebut tidak berbelok-belok, sehingga kecepatan kendaraan konstan;

2. Jalan memiliki 2 arah yang menjadi akses ke berbagai tujuan yang menjadikan volume kendaraan besar. Meskipun 2 arah, jalan tersebut hanya memiliki 2 jalur, sehingga pengamatan lebih terfokuskanJalan tersebut merupakan daerah sibuk karena memiliki banyak gedung perkantoran, pusat perbelanjaan, rumah sakit, sarana olahraga, dan universitas.
Pengamatan dilakukan dari jembatan penyeberangan yang berada di depan Indofood tower. Berdasarkan suvey lokasi, area ini memiliki volume kendaraan yang besar serta kecepatan yang rendah. Panjang jalan sebagai objek penelitian diambil $35 \mathrm{~m}$ (garis biru pada Gambar 1).

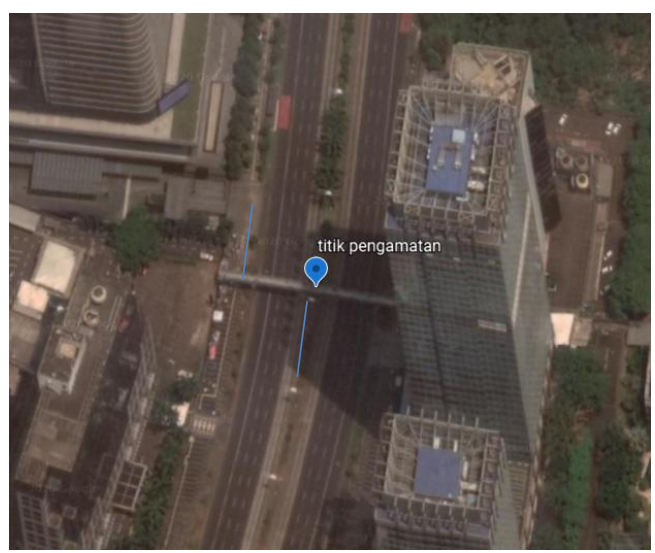

Gambar 1.

Lokasi Penelitian (https://rb.gy/8ae6ba, diakses September 2020)

\subsection{Pengumpulan data}

Dalam Penelitian ini terdapat dua jenis data yang dibutuhkan, yaitu dara primer dan data sekunder.

- Data primer meliputi pengumpulan data volume lalu lintas, kecepatan kendaraa, kelembapan udara, suhu udara, kecepatan angin, dan radiasi sinar matahari.

- Data Sekunder meliputi gambaran umum JI. Jenderal Sudirman, data BPS Provinsi DKI Jakarta, studi literatur serta artikel- 
artikel ilmiah terkait pencemaran udara dan model-model pencemaran udara.

\subsection{Pelaksanaan Sampling}

Metode pengukuran volume lalu lintas yang akan dilakukan ini sebelumnya pernah dilakukan Sengkey dkk. pada tahun 2011 di ruas jalan Sam Ratulangi Manado, yaitu pengukuran dilakukan pada hari Senin sebagai representatif hari kerja, Sabtu sebagai representatif hari setengah kerja dan setengah libur, dan Minggu sebagai representatif hari libur. Penelitian dilakukan dari pukul 06.00 sampai pukul 18.00, dimana waktu penelitian dibagi menjadi 3 kategori, yaitu jam puncak pagi, jam puncak siang, dan jam puncak sore. Jam puncak menunjukkan jam pada saat kendaraan memiliki jumlah kendaraan yang paling banyak. Jam puncak akan menunjukkan konsentrasi $\mathrm{CO}$ tertinggi pada hari penelitian. Jam puncak pagi dipilih dari pukul 06.00-10.00, jam puncak siang dipilih dari pukul 10.01-14.00, jam puncak sore dipilih dari pukul 14.01-18.00.

Pengukuran jumlah kendaraan dilakukan manual dengan menggunakan alat hitung manual. Dikarenakan adanya dua jalur dengan arah berbeda yang memiliki karakter lalu lintas berbeda, maka pengukuran volume lalu lintas dilakukan per jalur, dan dibutuhkan masing-masing 1 orang dalam proses pengukuran. Untuk melengkapi pengamatan, pengamat membawa 3 alat hitung manual (masing-masing untuk menghitung kendaraan roda empat, kendaraan roda di atas empat, dan sepeda motor), serta formulir untuk mencatat jumlah kendaraan masing-masing jenis setiap 1 jam pengukuran kecepatan kendaraan dan pengukuran parameter udara ambien.

Pengambilan data kecepatan yang dilakukan hanya pada jam puncak yang telah diperoleh di tahap pertama, dengan menghitung kecepatan masing-masing jenis kendaraan setiap 10 menit dalam satu jam, sehinga didapat 6 sampel untuk masing-masing jenis kendaraan (diasumsikan kondisi lalu lintas berubah tiap 10 menit, sehingga didapat kecepatan rata-rata yang menggambarkan kondisi lalu lintas dalam jam pucak tersebut).

Pengamatan dilakukan pada jam puncak dengan mengukur kecepatan kendaraan, mengukur suhu, kelembapan udara, kecepatan angin, konsentrasi $\mathrm{CO}$ dan mencatat stabilitas atmosfer.

Metode yang digunakan untuk menghitung kecepatan kendaraan adalah dengan mengukur waktu yang dibutuhkan oleh sampel untuk menempuh jarak $35 \mathrm{~m}$ (objek penelitian), kemudian kecepatan akan dihitung dengan persamaan (1).

$\mathrm{V}=\frac{s}{t}$

Dimana s adalah jarak (meter), t adalah waktu (detik), dan V adalah kecepatan (m/dtk). 
Kemudian pengukuran kelembapan udara dan suhu menggunakan higrometer yang juga memiliki fitur pengukur suhu, pengukuran kecepatan angin dengan anemometer.

Stabilitas atmosfer ditentukan berdasarkan kecepatan angin yang didapat lalu disesuaikan dengan radiasi matahari pada jam puncak dengan keterangan sebagai berikut (Permatasari A.A.I, 2014 [6]; Tjasyono, B. H. K., 2009 [7]):

1. "Strong" merupakan kondisi saat langit cerah tidak berawan.

2. "Moderate" merupakan kondisi saat awan sedikit menutup langit.

3. "Slight" merupakan kondisi saat sebagian besar langit tertutup awan atau mendung.

Kemudian data angin dan radiasi matahari disesuaikan dengan klasifikasi stabilitas atmosfer yang dibuat oleh Pasquil, dapat dilihat pada Tabel 2.

Tabel 2.

Klasifikasi Stabilitas Atmosfer (Pasquil 1961 dalam Chapman 2017 [8])

\begin{tabular}{cccccc}
\hline & \multicolumn{3}{c}{ Radiasi Matahari } & \multicolumn{4}{c}{ Kondisi Malam Hari } \\
\cline { 2 - 6 } $\begin{array}{c}\text { Kecepatan } \\
\text { Angin } \\
\text { (m/dtk) }\end{array}$ & Kuat & Moderat & Ringan & $\begin{array}{c}\text { Thin } \\
\text { Overcast } \\
\text { atau 4/8 } \\
\text { awan } \\
\text { rendah }\end{array}$ & $\begin{array}{c}</=4 / 8 \\
\text { berawan }\end{array}$ \\
\hline$<2$ & A & A-B & B & - & - \\
\hline $2-3$ & A-B & B & C & E & F \\
\hline $3-4$ & B & B-C & C & D & E \\
\hline $4-6$ & C & C-D & D & D & D \\
\hline$>6$ & C & D & D & D & D \\
\hline
\end{tabular}

\subsection{Pengolahan Data dan Analisis}

Pada penelitian ini, model yang dipakai adalah model dispersi Gaussian yang telah dimodifikasi untuk mencari konsentrasi CO dari kendaraan atau sumber bergerak. Modifikasi rumus yang sesuai untuk sumber pencemar garis yang berada di permukaan tanah dapat dilihat pada persamaan (2) berikut

$C(x, 0,0: 0)=\frac{Q}{\pi \sigma_{z} \sigma_{y} u}$

Untuk menghitung konsentrasi $\mathrm{CO}(\mathrm{C})$ dari persamaan tersebut, perlu mencari nilai laju emisi (Q), koefisien dispersi arah sumbu $Z$ $\left(\sigma_{z}\right)$, koefisien dispersi arah sumbu $Y\left(\sigma_{y}\right)$, dan kecepatan angin $(\mu)$.

Untuk mencari nilai $Q$ yang tertulis pada persamaan (3), dibutuhkan nilai $n$ atau jumlah kendaraan dan nilai q atau laju emisi. Jumlah kendaraan per satuan waktu ( $n$ ) diambil dari jumlah kendaraan pada jam puncak, untuk ketiga kategori jenis kendaraan akan dinormalisasikan dengan faktor pengali emisi CO pada Tabel 3. Kemudian laju emisi (q) dihitung dengan menggunakan persamaan (4) (Departemen Pekerjaan Umum, 1999 [9]).

$\mathrm{Q}=n \times q$

$q=867,92 \times V^{-0,8648}$

Dimana $Q$ adalah Kekuatan Emisi (gr/dtk atau gr/dtk.m), $n$ adalah jumlah kendaraan per detik. 
Tabel 3.

Faktor Pengali untuk Menormalisasi Volume Kendaraan menjadi Satuan Mobil Penumpang per Satuan Waktu [9]

\begin{tabular}{ccccc}
\hline & \multicolumn{4}{c}{ Faktor Pengali Emisi CO } \\
\cline { 2 - 5 } $\begin{array}{c}\text { Jenis } \\
\text { Kendaraan }\end{array}$ & Metropolitan & $\begin{array}{c}\text { Kota } \\
\text { Besar }\end{array}$ & $\begin{array}{c}\text { Kota } \\
\text { Sedang }\end{array}$ & $\begin{array}{c}\text { Lain- } \\
\text { lain }\end{array}$ \\
\hline $\begin{array}{c}\text { Sepeda } \\
\text { Motor }\end{array}$ & 0,6 & 0,6 & 0,60 & 0,60 \\
\hline $\begin{array}{c}\text { Kendaraan } \\
\text { Penumpang }\end{array}$ & 1 & 0,76 & 0,80 & 0,76 \\
\hline $\begin{array}{c}\text { Kendaraan } \\
\text { Berat }\end{array}$ & 1,97 & 1,93 & 1,95 & 1,93 \\
\hline
\end{tabular}

Penghitungan dispersi $\left(\sigma_{z}\right.$ dan $\left.\sigma_{y}\right)$ mengunakan persamaan (5) dan (6) [9].

$\sigma_{z=} c x^{d}+f$

$\sigma_{\mathrm{y}}=\mathrm{ax}^{0,8}$

Nilai konstanta $a, c, d$, dan $f$ ditentukan berdasarkan stabilitas atmosfer dikaitkan dengan jarak reseptor $\left(\mathrm{x}_{\mathrm{f}}\right)$. Nilai konstanta tersebut dirumuskan oleh D.O Martin berdasarkan beberapa rangkaian percobaan, dapat dilihat pada Tabel 4.

Tabel 4.

Nilai konstanta $a, c, d$, dan $f$ untuk menghitung $\sigma_{y}$ dan $\sigma_{z}$ sebagai fungsi dari jarak (Martin 1976 dalam Cooper dan Alley, 1994 [10])

\begin{tabular}{cccccccc}
\hline & \multicolumn{4}{c}{$\mathbf{X}<1 \mathbf{k m}$} & \multicolumn{4}{c}{ X>1 km } \\
\cline { 2 - 8 } Kelas \\
\cline { 2 - 8 } & $\mathbf{a}$ & $\mathbf{C}$ & $\mathbf{d}$ & $\mathbf{F}$ & $\mathbf{c}$ & $\mathbf{d}$ & $\mathbf{f}$ \\
\hline A & 213 & 440,8 & 1,941 & 9,27 & 459,7 & 2,094 & $-9,6$ \\
\hline B & 156 & 100,6 & 1,149 & 3,3 & 108,2 & 1,098 & 2 \\
\hline C & 104 & 61 & 0,911 & 0 & 61 & 0,911 & 0 \\
\hline D & 68 & 33,2 & 0,725 & $-1,7$ & 44,5 & 0,516 & -13 \\
\hline E & 50,5 & 22,8 & 0,678 & 1,3 & 55,4 & 0,305 & -34 \\
\hline F & 34 & 14,35 & 0,74 & $-0,35$ & 62,6 & 0,18 & $-48,6$ \\
\hline
\end{tabular}

Setelah konsentrasi CO didapatkan dari persamaan (2), konsentrasi CO dibandingkan dengan baku mutu udara ambien nasional berdasarkan PP No. 41 Tahun 1999. Selain itu, konsentrasi yang didapatkan dari pemodelan dibandingkan lagi dengan konsentrasi $\mathrm{CO}$ yang diukur oleh $\mathrm{CO}$ meter, untuk mengetahui presentase konsentrasi $\mathrm{CO}$ di udara yang dihasilkan oleh kendaraan di lokasi penelitian.

\section{ANALISIS DAN PEMBAHASAN}

\subsection{Volume Lalu Lintas}

Volume lalu lintas pada hari Senin yang mewakili hari kerja dapat dilihat pada Gambar 2.

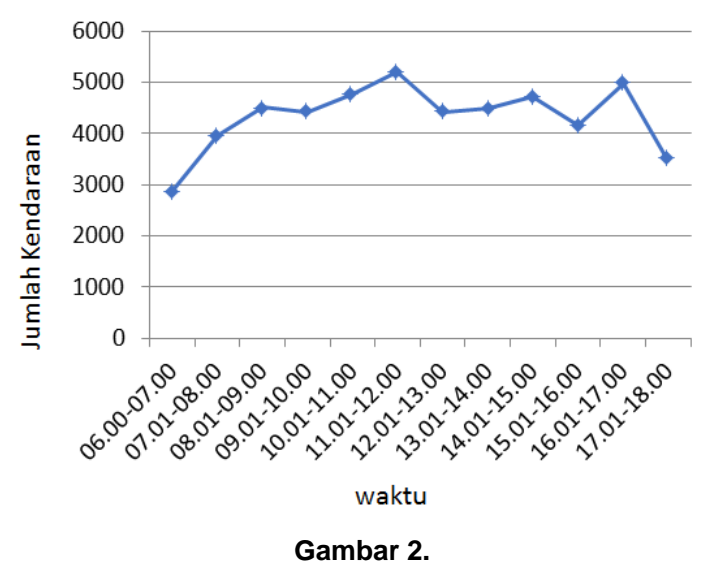

Grafik Jumlah Kendaraan Total Pada Hari Senin

Berdasarkan Gambar 2, dapat diketahui jam puncak pagi terjadi pada pukul 08.01-09.00 dengan jumlah kendaraan 9199, jam puncak siang terjadi pada pukul 11.01-12.00 dengan jumlah kendaraan 8426, dan jam puncak sore terjadi pada pukul 16.01-17.00 dengan jumlah 
kendaraan 8930. Kepadatan yang terjadi di hari Senin diakibatkan tingginya aktivitas masyarakat yang terjadi pada hari kerja, terlihat pada jam puncak pagi dan jam puncak siang dengan volume lalu lintas yang tinggi karena pada jam tersebut terjadi aktivitas pergi dan pulang kerja.

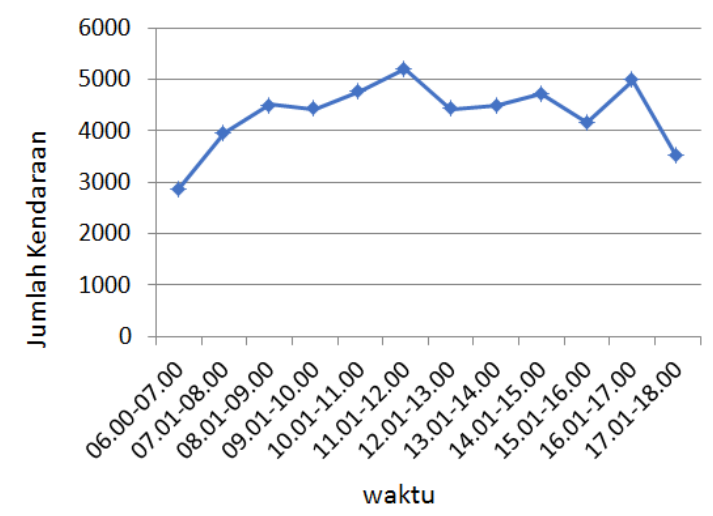

Gambar 3.

Grafik Jumlah Kendaraan Total Pada Hari Sabtu

Volume kendaraan dihari Sabtu yang mewakili hari saat kegiatan setengah hari kerja dapat dilihat pada Gambar 3. Gambar di atas menunjukkan jam puncak pagi terjadi pada pukul 08.01-09.00 dengan jumlah kendaraan 4507, jam puncak siang terjadi pada pukul 11.01-12.00 dengan jumlah kendaraan 5200, dan jam puncak sore terjadi pada pukul 16.0117.00 dengan jumlah kendaraan 4974. Volume kendaraan pada hari Sabtu lebih sedikit dibandingkan voulme lalu lintas pada hari Senin, karena tidak banyak orang yang bekerja pada hari sabtu sehingga sedikitnya aktivitas lalu lintas.

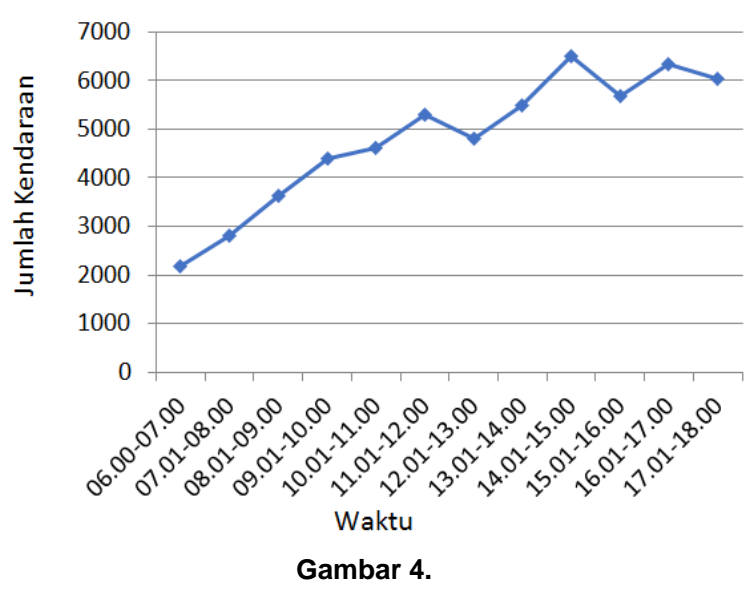

Grafik Jumlah Kendaraan Total Pada Hari Minggu

Gambar 4 di atas menunjukkan volume lalu lintas pada hari Minggu yang mewakili hari libur. Dari pengamatan, didapat jam puncak pagi pada pukul 09.01-10.00 dengan jumlah kendaraan 4395, jam puncak siang pada pukul 13.01-14.00 dengan jumlah kendaraan 5496, dan jam puncak sore pada pukul 14.0115.00 dengan jumlah kendaraan 6494 .

Kecilnya volume lalu lintas pada hari Minggu pagi dikarenakan adanya Car Free Day (CFD) dilaksanakan di Jl. Jenderal Sudirman setiap hari Minggu pukul 06.00-10.00. Dikarenakan adanya pandemi Covid 19, maka CFD hanya memakai setengah jalan di tiap jalurnya, sebagian lain dipakai untuk jalur kendaraan.

Langkah selanjutnya adalah menormalisasi jumlah kendaraan yang dihitung dengan mengalikan jumlah kendaraan/dtk dengan 
faktor pengali emisi $\mathrm{CO}$ yang dapat dilihat pada Tabel 3 untuk menjadi satuan mobil penumpang per satuan waktu (smp/dtk). Dari hasil perkalian tersebut, didapat hasil yang dapat dilihat pada Tabel 5.

Tabel 5.

Hasil Perhitungan Normalisasi Kendaraan Penumpang

\begin{tabular}{|c|c|c|c|c|c|c|}
\hline \multirow[b]{2}{*}{ Waktu } & \multicolumn{3}{|c|}{$\begin{array}{c}\text { Hasil Normalisasi } \\
\text { Kendaraan (smp/dtk) } \\
\text { (Arah Utara) }\end{array}$} & \multicolumn{3}{|c|}{$\begin{array}{c}\text { Hasil Normalisasi } \\
\text { Kendaraan (smp/dtk) } \\
\text { (Arah Selatan) }\end{array}$} \\
\hline & $\begin{array}{c}\text { Roda } \\
2 \\
\end{array}$ & $\begin{array}{c}\text { Roda } \\
4 \\
\end{array}$ & $\begin{array}{c}\text { Roda } \\
>4\end{array}$ & $\begin{array}{c}\text { Roda } \\
2 \\
\end{array}$ & $\begin{array}{c}\text { Roda } \\
4 \\
\end{array}$ & $\begin{array}{c}\text { Roda } \\
>4\end{array}$ \\
\hline \multicolumn{7}{|c|}{ Senin } \\
\hline pagi & 0,566 & 0,851 & 0,057 & 0,262 & 0,284 & 0,021 \\
\hline siang & 0,440 & 0,662 & 0,044 & 0,265 & 0,471 & 0,021 \\
\hline sore & 0,491 & 0,837 & 0,044 & 0,228 & 0,99 & 0,047 \\
\hline \multicolumn{7}{|c|}{ Sabtu } \\
\hline pagi & 0,193 & 0,209 & 0,040 & 0,238 & 0,296 & 0,030 \\
\hline siang & 0,105 & 0,337 & 0,044 & 0,241 & 0,494 & 0,028 \\
\hline sore & 0,095 & 0,328 & 0,046 & 0,215 & 0,510 & 0,027 \\
\hline \multicolumn{7}{|c|}{ Minggu } \\
\hline pagi & 0,228 & 0,224 & 0,030 & 0,222 & 0,214 & 0,032 \\
\hline siang & 0,208 & 0,467 & 0,037 & 0,163 & 0,405 & 0,033 \\
\hline sore & 0,300 & 0,485 & 0,034 & 0,174 & 0,497 & 0,030 \\
\hline
\end{tabular}

\subsection{Laju Emisi}

Data kecepatan dibutuhkan untuk menghitung laju emisi. Cara mendapatkan data kecepatan adalah dengan mengukur waktu yang dibutuhkan kendaraan dalam menempuh $35 \mathrm{~m}$ panjang jalan. Data kecepatan yang diukur dilapangan memiliki satuan $\mathrm{m} / \mathrm{dtk}$, kemudian diubah $\mathrm{ke} \mathrm{km/jam.} \mathrm{Hasil} \mathrm{konversi} \mathrm{dapat} \mathrm{dilihat}$ pada Tabel 6.
Tabel 6.

Kecepatan Kendaraan (V)

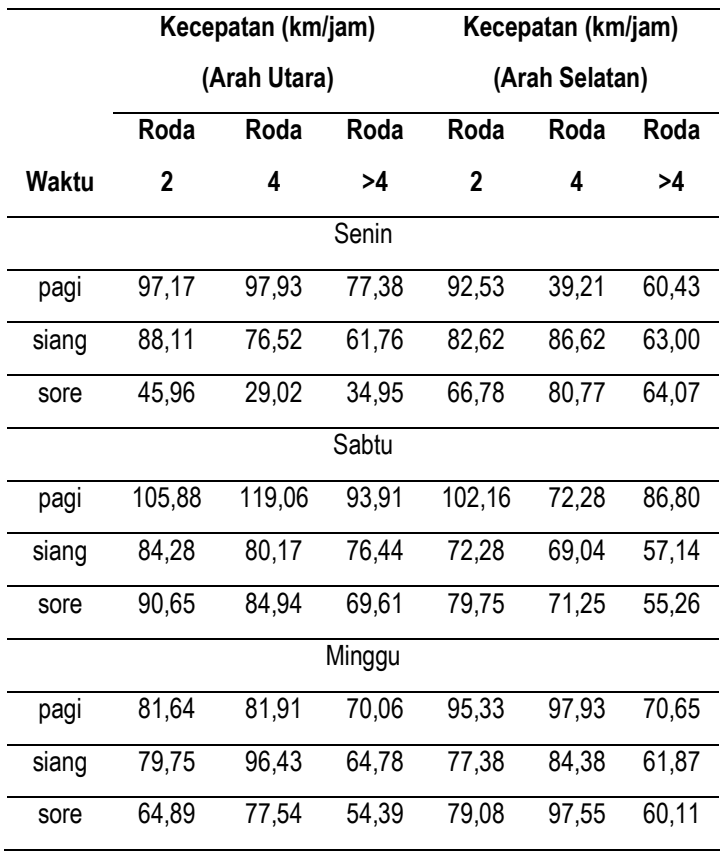

Setelah mengubah satuan kecepatan, lalu dilanjutkan dengan menghitung laju emisi (q) menggunakan persamaan (3) .Hasil perhitungan laju emisi tersebut dapat dilihat pada Tabel 7. Dari hasil perkalian tersebut dapat diketahui bahwa laju emisi tertinggi ratarata terdapat di hari Senin sore di jalur arah utara. Jika dilihat dari kecepatan, kecepatan kendaraan di hari Senin sore di jalur arah utara memiliki kecepatan yang lebih rendah untuk tiap jenis kendaraannya dibanding dengan waktu lain. 
Tabel 7.

Laju Emisi (qCO)

\begin{tabular}{|c|c|c|c|c|c|c|}
\hline \multirow[b]{3}{*}{ Waktu } & \multicolumn{3}{|c|}{$\begin{array}{c}\text { qCO (gr/km) (Arah } \\
\text { Utara) }\end{array}$} & \multicolumn{3}{|c|}{$\begin{array}{c}\text { qCO (gr/km) (Arah } \\
\text { Selatan) }\end{array}$} \\
\hline & Roda & Roda & Roda & Roda & Roda & Roda \\
\hline & 2 & 4 & $>4$ & 2 & 4 & $>4$ \\
\hline \multicolumn{7}{|c|}{ Senin } \\
\hline pagi & 16,58 & 16,47 & 20,19 & 17,30 & 36,35 & 25,01 \\
\hline siang & 18,05 & 20,39 & 24,54 & 19,08 & 18,30 & 24,12 \\
\hline sore & 31,69 & 47,15 & 40,15 & 22,94 & 19,46 & 23,77 \\
\hline \multicolumn{7}{|c|}{ Sabtu } \\
\hline pagi & 15,40 & 13,91 & 17,08 & 15,88 & 21,42 & 18,28 \\
\hline siang & 18,75 & 19,58 & 20,41 & 21,42 & 22,29 & 26,25 \\
\hline sore & 17,61 & 18,63 & 22,13 & 19,67 & 21,69 & 27,02 \\
\hline \multicolumn{7}{|c|}{ Minggu } \\
\hline pagi & 19,28 & 19,22 & 22,00 & 16,86 & 16,47 & 21,84 \\
\hline siang & 19,67 & 16,69 & 23,55 & 20,19 & 18,74 & 24,50 \\
\hline sore & 23,51 & 20,16 & 27,39 & 19,82 & 16,53 & 25,12 \\
\hline
\end{tabular}

\subsection{Kekuatan Emisi}

Kekuatan emisi (Q) dihitung dengan mengalikan jumlah kendaraan yang telah dinormalisasi menjadi satuan mobil penumpang per satuan waktu dengan laju emisi (q). Hasil perhitungan dapat dilihat pada Tabel 8.

Berdasarkan hasil perkalian tersebut nilai kekuatan emisi terbesar terdapat di hari senin sore arah utara, dan kekuatan emisi terkecil pada hari Sabtu pagi arah utara. Hal ini sebanding dengan laju emisi yang telah dihitung sebelumnya.
Tabel 8.

Kekuatan Emisi (Q)

\begin{tabular}{|c|c|c|c|c|c|c|c|c|}
\hline \multirow[b]{3}{*}{ Waktu } & \multicolumn{4}{|c|}{$Q$ (gr/dtk) (Arah Utara) } & \multicolumn{4}{|c|}{$Q$ (gr/dtk) (Arah Selatan) } \\
\hline & Roda & Roda & Roda & $\mathbf{Q}$ & Roda & Roda & Roda & $Q$ \\
\hline & 2 & 4 & $>4$ & total & 2 & 4 & $>4$ & total \\
\hline \multicolumn{9}{|c|}{ Senin } \\
\hline pagi & 9,38 & 14,02 & 1,15 & 24,55 & 4,53 & 10,32 & 0,53 & 15,38 \\
\hline siang & 7,94 & 13,50 & 1,08 & 22,52 & 5,06 & 8,62 & 0,51 & 14,18 \\
\hline sore & 15,56 & 39,46 & 1,77 & 56,79 & 5,23 & 19,27 & 1,12 & 25,61 \\
\hline \multicolumn{9}{|c|}{ Sabtu } \\
\hline pagi & 2,97 & 2,91 & 0,68 & 6,56 & 3,78 & 6,34 & 0,55 & 10,67 \\
\hline siang & 1,97 & 6,60 & 0,90 & 9,47 & 5,16 & 11,01 & 0,74 & 16,91 \\
\hline sore & 1,67 & 6,11 & 1,02 & 8,80 & 4,23 & 11,06 & 0,73 & 16,02 \\
\hline \multicolumn{9}{|c|}{ Minggu } \\
\hline pagi & 4,40 & 4,31 & 0,66 & 9,36 & 3,74 & 3,52 & 0,70 & 7,97 \\
\hline siang & 4,09 & 7,79 & 0,87 & 12,76 & 3,29 & 7,59 & 0,81 & 11,69 \\
\hline sore & 7,05 & 9,78 & 0,93 & 17,76 & 3,45 & 8,22 & 0,75 & 12,42 \\
\hline
\end{tabular}

\subsection{Dispersi}

Dalam menentukan Kelas Stabilitas Atmosfer, diperlukan data radiasi matahari dan kecepatan angin pada saat pengamatan. Data kecepatan angin diperoleh dengan pengukuran menggunakan anemometer.

Data kecepatan angin digunakan untuk menentukan kelas stabilitas atmosfer yang dicocokkan dengan kondisi radiasi matahari pada saat pengamatan. Data tersebut dapat dilihat pada Tabel 9. 
Tabel 9.

Stabilitas Atmosfer

\begin{tabular}{cccc}
\hline & Radiasi & $\begin{array}{c}\text { Kecepatan } \\
\text { Angin } \\
\text { Waktu } \\
\text { Matahari }\end{array}$ & $\begin{array}{c}\text { Kelas } \\
\text { Stabilitas } \\
\text { Atmosfer }\end{array}$ \\
\hline pagi & strong & 1,8 & $\mathrm{~A}$ \\
\hline siang & moderate & 1,8 & $\mathrm{~A}-\mathrm{B}$ \\
\hline sore & strong & 1,6 & $\mathrm{~A}$ \\
\hline pagi & moderate & 1,1 & $\mathrm{~A}-\mathrm{B}$ \\
\hline siang & moderate & 2,1 & $\mathrm{~B}$ \\
\hline sore & moderate & 2 & $\mathrm{~B}$ \\
\hline & & Rabu & \\
\hline pagi & slight & 1,2 & $\mathrm{~B}$ \\
\hline siang & slight & 1,8 & $\mathrm{~B}$ \\
\hline sore & moderate & 1,4 & $\mathrm{~A}-\mathrm{B}$ \\
\hline
\end{tabular}

Tabel 10.

Standar Deviasi Sebaran pada Arah z dan y

\begin{tabular}{|c|c|c|c|c|c|c|}
\hline \multirow{2}{*}{$\begin{array}{c}\text { Kelas } \\
\text { Stabilitas }\end{array}$} & \multicolumn{4}{|c|}{$x<1 \mathrm{~km}$} & \multirow{2}{*}{$\sigma_{\mathrm{x}}$} & \multirow{2}{*}{$\sigma_{y}$} \\
\hline & a & C & $d$ & $F$ & & \\
\hline A & 213 & 440,8 & 1,941 & 9,27 & 27,188 & 24,009 \\
\hline$B$ & 156 & 100,6 & 1,149 & 3,3 & 19,912 & 17,580 \\
\hline$A-B$ & & & & & 23,550 & 20,797 \\
\hline
\end{tabular}

\subsection{Prediksi Konsentrasi Polutan}

Perhitungan prediksi konsentrasi $\mathrm{CO}$ dengan persamaan dispersi Gaussian dapat dilakukan karena telah didapatkan data-data yang dibutuhkan, yaitu data kecepatan angin, data standar deviasi sebaran arah $\mathrm{z}$ dan $\mathrm{y}$, dan data kekuatan emisi. Hasil perhitungannya dapat dilihat pada Tabel 11.
Tabel 11.

Hasil Perhitungan Konsentrasi CO dengan Persamaan Gaussian

\begin{tabular}{cccc}
\hline Waktu & Utara & Selatan & $\begin{array}{c}\text { C Total } \\
(\mu \mathrm{g} / \mathrm{m} 3)\end{array}$ \\
\hline \multicolumn{3}{c}{ Senin } \\
\hline pagi & 6658 & 4169 & 5700 \\
\hline siang & 7571 & 5099 & 6576 \\
\hline sore & 14788 & 4090 & 12469 \\
\hline \multicolumn{3}{c}{ Sabtu } \\
\hline pagi & 3826 & 6299 & 5364 \\
\hline siang & 4103 & 7323 & 6166 \\
\hline sore & 3797 & 7288 & 6091 \\
\hline \multicolumn{3}{c}{ Minggu } \\
\hline pagi & 7108 & 4320 & 5826 \\
\hline siang & 6448 & 5914 & 6181 \\
\hline sore & 8244 & 8062 & 8152 \\
\hline
\end{tabular}

Konsentrasi CO dari hasil pemodelan dengan menggunakan persamaan dispersi Gaussian diatas masih dipisah dalam 2 kategori, yaitu konsentrasi $\mathrm{CO}$ dari kendaraan menuju utara dan konsentrasi $\mathrm{CO}$ dari kendaraan menuju arah selatan. Proses perhitungan ini dipisahkan berdasarkan jalur, karena karakter lalu lintas yang berbeda tiap jalur, dari segi kecepatan kendaraan maupun volume lalu lintas. Untuk mendapatkan nilai pencampuran konsentrasi CO dari kedua jalur, maka digunakanlah Persamaan (7) berikut.

$C=\frac{\text { Qi utara } \times \text { Ci utara } i+Q i \text { selatan } \times \text { Ci selatan }}{\text { Qi utara }+Q \text { i selatan }}$

Dimana:C adalah konsentrasi CO $\left(\mu \mathrm{g} / \mathrm{m}^{3}\right), \mathrm{Q}$ adalah kekuatan emisi (gr/dtk), dan i adalah waktu pengamatan. 
Dari data prediksi konsentrasi $\mathrm{CO}$, konsentrasi tertinggi didapat pada hari Senin sore sebesar $12469 \mu \mathrm{g} / \mathrm{m}^{3}$. Hal tersebut dikarenakan besarnya volume lalu lintas dan kecepatan kendaraan yang relatif rendah. Apabila dibandingkan dengan kendaraan pada hari Senin pagi, jumlah kendaraan pada hari Senin sore lebih sedikit, namun kecepatan kendaraan pada Senin pagi lebih tinggi. Oleh karena itu, kecepatan sangat mempengaruhi besarnya konsentrasi $\mathrm{CO}$ yang dikeluarkan oleh kendaraan. Hari kerja memberikan kepadatan lalu lintas yang lebih tinggi dibandingkan dengan hari libur, dan kondisi sore hari memperlihatkan kondisi kepadatan yang lebih tinggi dibandingkan dengan pagi hari karena rentang waktu yang pendek bagi pekerja untuk pulang dari tempat kerja menuju ke rumah (Wahyuni dkk., 2019 [11])

Hari Sabtu pagi merupakan kondisi lalu lintas dengan nilai konsentrasi $\mathrm{CO}$ paling rendah, meskipun volume kendaraan lebih tinggi dibandingkan dengan hari Minggu pagi. Kondisi ini disebabkan oleh rendahnya kecepatan kendaraan di hari Minggu pagi akibat adanya CFD dan tingginya kecepatan kendaraan pada hari Sabtu pagi, hal ini juga menunjukkan bahwa kecepatan sangat berpengaruh terhadap konsentrasi $\mathrm{CO}$ yang dikeluarkan. CFD mereduksi emisi sebesar 60,4\% (Indria dan Ali, 2015 [12]).
Selain memprediksi konsentrasi CO dengan persamaan dispersi Gaussian, dilakukan juga pengukuran udara ambien menggunakan $\mathrm{CO}$ meter. Hasil pengukuran dengan $\mathrm{CO}$ meter dapat dilihat pada Tabel 12 Beserta presentase selisihnya, cara menghitung presentase selisihnya adalah dengan menggunakan Persamaan (8).

$\mathrm{E}=\frac{a-b}{a} \times 100 \%$

Dimana $E$ adalah selisih hitung data hasil pengukuran dan data hasil pemodelan, a adalah data hasil pengukuran lapangan, dan $b$ adalah data hasil perhitungan dengan pemodelan (Fu'adah dkk., 2018 [13]).

Tabel 12.

Perbandingan Konsentrasi Hasil Pemodelan dengan Pengukuran Udara Ambien

\begin{tabular}{|c|c|c|c|c|}
\hline \multirow[b]{2}{*}{ Waktu } & \multirow{2}{*}{$\begin{array}{l}\text { Konsentrasi } \\
\text { hasil model } \\
(\mathrm{ppm})\end{array}$} & \multirow{2}{*}{$\begin{array}{l}\text { Konsentrasi } \\
\text { hasil } \\
\text { pengukuran } \\
(\mathrm{ppm})\end{array}$} & \multicolumn{2}{|c|}{ Selisih } \\
\hline & & & ppm & $(\%)$ \\
\hline \multicolumn{5}{|c|}{ Senin } \\
\hline pagi & 4.99 & 4.00 & 0.99 & 24.75 \\
\hline siang & 5.75 & 5.00 & 0.75 & 15.00 \\
\hline sore & 10.91 & 9.00 & 1.91 & 21.22 \\
\hline \multicolumn{5}{|c|}{ Sabtu } \\
\hline pagi & 4.69 & 4.00 & 0.69 & 17.25 \\
\hline siang & 5.40 & 5.00 & 0.40 & 8.00 \\
\hline sore & 5.33 & 5.00 & 0.33 & 6.60 \\
\hline \multicolumn{5}{|c|}{ Minggu } \\
\hline pagi & 5.10 & 5.00 & 0.10 & 2.00 \\
\hline siang & 5.42 & 5.00 & 0.42 & 8.40 \\
\hline sore & 7.15 & 7.00 & 0.15 & 2.14 \\
\hline
\end{tabular}


Presentase selisih antara pengukuran udara ambien menggunakan $\mathrm{CO}$ meter dengan hasil pemodelan cukup tinggi, yaitu antara $2 \%-25 \%$, dimana keseluruhan data hasil perhitungan memiliki nilai yang lebih tinggi. Pada kondisi ini banyak hal yang mempengaruhi, yaitu:

1. Alat $\mathrm{CO}$ meter tidak memiliki detail desimal, sehingga tidak dapat menunjukkan angka desimalnya.

2. Data kecepatan kendaraan yang kurang menunjukkan kondisi lalu lintas.

3. Perbedaan data kecepatan angin yang diperoleh untuk perhitungan dengan kecepatan angin yang saat dilakukan pengukuran udara ambien.

4. Stabilitas atmosfer yang ditentukan kurang tepat, karena berpengaruh terhadap penentuan nilai $\sigma_{\mathrm{y}}$ dan $\sigma_{\mathrm{z}}$.

Secara keseluruhan, konsentrasi karbon monoksida yang terukur dan terhitung di Jalan Sudirman Jakarta pada saat penelitian ini masih memenuhi baku mutu. $\mathrm{Hal}$ ini diperlihatkan dari nilai karbon monoksida yang masih di bawah konsentrasi maksimum yang ditetapkan dalam baku mutu sebesar 30000 ppm.

\section{KESIMPULAN}

Berdasarkan hasil penelitian, dapat disimpulkan beberapa hal, diantaranya:
1. Prediksi konsentrasi CO yang dihasilkan oleh kendaraan dengan pemodelan berada diantara 5364 ppm hingga 12469 ppm.

2. Konsentrasi $\mathrm{CO}$ paling besar terdapat pada hari Senin Sore, dan paling kecil pada hari sabtu pagi

3. Besarnya volume lalu lintas mempengaruhi nilai konsentrasi $\mathrm{CO}$ yang dihasilkan, namun kecepatan juga berperan besar. Dapat dilihat bahwa volume kendaraan pada hari Senin pagi merupakan volume lalu lintas terbesar, namun konsentrasi $\mathrm{CO}$ pada hari Senin sore lebih besar karena kecepatan kendaraan yang relatif lebih pelan.

4. Konsentrasi CO yang dihasilkan oleh kendaraan di Jl. Jenderal Sudirman tidak melampaui baku mutu udara ambien, yaitu 30000 ppm.

5. Presentase selisih konsentrasi CO dari hasil pemodelan dengan pengukuran udara ambien berkisar $2 \%$ hingga $25 \%$.

\section{DAFTAR PUSTAKA}

[1] Hasbiah, A.W., Mulyatna, L., Musaddad, F. 2016. Studi Identifikasi Pencemaran Udara Oleh Timbal (Pb) Pada Area Parkir (Studi Kasus Kampus Universitas Pasundan Bandung). Jurnal Infomatek, Vol. 18(1), pp. 49-56. 
[2] Fahmi, M. I., Mawardi, W. H, 2007. Analisis Tingkat Kebutuhan Bis Sekolah di Kota Semarang (studi kasus: SMU Ksatrian / SMP 1 Ksatrian, SMPN 3 Semarang, SMPN 32 Semarang, SD Santo Yusuf, dan SMA Sedes Sapientiae / SMP Maria Mediatrix) http://eprints.undip. ac.id/34218/, diakses 7 Februari 2020

[3] BPS DKI Jakarta, 2019, Jumlah Kendaraan Bermotor Menurut Provinsi dan Jenis.

[4] Maryanto, D., 2009 Penurunan Kadar Emisi Gas Buang Karbon Monoksida (CO) dengan Penambahan Arang Aktif pada Kendaraan Bermotor di Yogyakarta, Jurnal KES MAS, Vol. 3, No. 3, 162-232, Yogyakarta

[5] Hoesodo, D., 2004, Permodelan Pencemaran Udara Akibat Lalu Lintas di Jalan Arteri (Studi Kasus Ruas Jalan Soekarno-Hatta di KotaBandung), Tesis, Univeritas Diponegoro, Semarang

[6] Permatasari A.A.I. 2014. Analisis Pemetaan Kualitas Udara Ambien Menggunakan Perangkat Lunak ARCGIS 10 dan Model Dispersi Gauss (Studi Kasus Kawasan Bukin Semarang Baru Kecamatan Mijen, Kota Semarang), Tesis, Semarang. http://eprints.undip.ac.id/43667 /3/BAB_II.pdf diakses 2 Oktober 2020
[7] Tjasyono, B. H. K., 2009, Meteorologi Indonesia Volume I, BMKG, Jakarta. https://staklimjogja.files.wordpress.com/20 17/02/meteo-indonesia-i.pdf diakses: 2 Oktober 2020

[8] Chapman, H. L., 2017, Performance Test of the Pasquill Stability Classification Scheme, thesis, Milwaukee: University of Winsconsin Milwaukee.

[9] Departemen Pekerjaan Umum, 1999, Tata Cara Prediksi Polusi Udara Skala Mikro Akibat Lalu Lintas, Mediatama Saptakarya, Jakarta

[10] Cooper, D dan Alley, F. 1994. Air Pollution Control. A Design Approach. Secound Edition. Waveland press Inc. USA.

[11]Wahyuni, S., Yustiani, Y.M., Juliandahri, A. 2019. Analisis Tingkat Kebisingan Lalu Lintas di Jalan Cihampelas dan Jalan Sukajadi Kota Bandung. Journal of Community Based Environmental Engineering and Management. Vol. 2(1), pp. 9-12.

[12] Indria, Ali, M. 2015. Pengaruh Program Car Free Day terhadap Penurunan Beban Pencemar CO dan NO2. Envirotek Jurnal IImiah Teknik Lingkungan. Vol. 7(2), pp. 68-74.

[13] Fu'adah, L.N., Ariyanto, A.D.P., Samsuri, H.H., Nugraheni, I.R. 2018. Kajian Indeks Stabilitas Atmosfer terhadap Kejadian 
Infomatek Volume 23 Nomor 1 Juni $2021: 55$ - 68

Hujan Lebat di Wilayah Bogor. Prosiding Seminar Nasional Fisika dan Aplikasinya. https://jurnal.uns.ac.id/prosidingsnfa/article /view/28538, diakses Mei 2021. 